\title{
RELEVANSI NILAI INFORMASI AKUNTANSI: STUDI KOMPARASI ANTARA SAHAM SYARIAH DAN SAHAM NON-SYARIAH DI BURSA EFEK INDONESIA (PERIODE 2013-2016)
}

\author{
Purnama Siddi \\ Universitas Islam Batik Surakarta \\ purnama.siddi@yahoo.com
}

\begin{abstract}
Stocks in the Indonesia Stock Exchange that enter into the list of Shariah securities (DES) tend to increase over time. This study aims to examine whether Sharia shares have an impact on the value relevance of accounting information. The test was conducted using 1,070 observations consisting of 852 sharia shares and 218 nonsharia shares included in the non-financial sector. Comparison is done by testing the influence of book value per share (BVPS) and earnings per share (EPS) on stock market price (PRICE). The result of the research shows that (1) BVPS has a positive effect on PRICE but only for sharia shares, so the value relevance of BVPS for sharia stocks is higher than the value relevance of BVPS for non-sharia stock. (2) EPS has positive effect on PRICE both for sharia stock and for non-sharia stocks, but the effect of EPS on PRICE is higher for non-sharia shares.
\end{abstract}

Keys: Sharia share, non-sharia share, book value per share and earning per share

\section{Abstrak}

Saham di Bursa Efek Indonesia yang masuk ke dalam daftar efek syariah (DES) cenderung meningkat dari waktu ke waktu. Penelitian ini bertujuan untuk menguji apakah saham syariah mempunyai dampak pada relevansi nilai informasi akuntani. Pengujian dilakukan dengan menggunakan sampel sebanyak 1.070 observasi yang terdiri dari 852 saham syariah dan 218 saham non-syariah yang termasuk dalam sektor non keuangan. Perbandingan dilakukan dengan menguji pengaruh nilai buku ekuitas per saham (book value per share, BVPS) dan laba per saham (earnings per share, EPS) terhadap harga pasar saham (PRICE). Hasil penelitian menunjukkan bahwa (1) BVPS berpengaruh positif pada PRICE tetapi hanya untuk saham syariah, sehingga relevansi nilai BVPS untuk saham syariah lebih tinggi dibandingkan dengan relevansi nilai BVPS untuk saham non-syariah, (2) EPS berpengaruh positif terhadap PRICE baik untuk saham syariah maupun untuk saham nonsyariah, dan pengaruh EPS tersebut terhadap PRICE lebih tinggi untuk saham non-syariah.

Kata kunci: saham syariah, saham non-syariah, nilai buku ekuitas per saham dan laba per saham

\section{PENDAHULUAN}

Data statistik yang dikeluarkan oleh Otoritas Jasa Keuangan (OJK) menunjukkan perkembangan jumlah saham dari waktu ke waktu. Suatu saham dapat dikategorikan sebagai saham syariah jika saham tersebut mempunyai karakteristik tertentu sebagai berikut. Emiten menyatakan secara jelas dalam anggaran dasarnya bahwa kegiatan usahanya tidak bertentangan dengan prinsip-prinsip syariah. Kegiatan usaha tidak bertentangan dengan prinsip syariah diatur dalam Peraturan Bapepam dan LK Nomor IX.A.13 tentang Penerbitan Efek Syariah IX.A.13, yaitu: tidak melakukan kegiatan usaha: perjudian dan permainan yang tergolong judi, perdagangan yang tidak disertai dengan penyerahan barang/jasa, perdagangan dengan penawaran/permintaan palsu, bank berbasis bunga, perusahaan pembiayaan berbasis bunga, jual beli risiko yang mengandung unsur ketidakpastian(gharar) dan/atau judi (maisir), antara lain asuransi konvensional, mendistribusikan, memperdagangkan dan/atau menyediakan barang atau jasa haram zatnya (haram li-dzatihi), barang atau jasa haram bukan karena zatnya (haram li-ghairihi) yang ditetapkan oleh DSN-MUI; dan/atau, barang atau jasa yang merusak moral dan bersifat mudarat, melakukan transaksi yang mengandung unsur suap (risywah). Di samping itu, perusahaan tersebut harus mempunyai rasio total hutang berbasis bunga dibandingkan total ekuitas tidak lebih dari 
$82 \%$ dan rasio total pendapatan bunga dan total pendapatan tidak halal lainnya dibandingkan total pendapatan usaha dan total pendapatan lainnya tidak lebih dari $10 \%$.

Penelitian sebelumnya yang berkaitan dengan saham syariah telah dilakukan dengan berbagai fokus seperti perbandingan determinan saham syariah dan non-syariah di Malaysia (Albaity, 2011), perbandingan faktor-faktor yang mempengaruhi PER saham syariah dan saham biasa untuk perusahaan nonkeuangan di Indonesia (Ratnaningrum \& Susilowati, 2011), pengukuran kinerja dengan bank syariah dengan MaqasidBased Model (Mohammed et al., 2015), ethical screening dan kinerja keuangan (Nainggolan et al.,2016), dan dampak shari'ah screening terhadap abnormal returns di Indonesia (Ashraf, 2016), perbandingan kinerja returns dari equity funds syariah dengan kinerja returns dari social responsible equity funds (Bukhari \& Azam, 2015). Beberapa penelitian lain di Indonesia tentang perbandingan antara saham syariah dan saham non-syariah menguji dan mendapatkan temuan yang bervariasi, seperti saham syariah lebih berisiko dibandingkan dengan saham nonsyariah meskipun hanya pada bulan-bulan tertentu saja (Buchdadi et al., 2010), tidak terdapat perbedaan antara saham syariah dan saham non-syariah (Rosyida \& Mawardi, 2015); Saputra \& Indriani, 2016), perbedaan karakteristik antara saham syariah dan non-syariah (Hamzah, 2011, Suhendi \& Indriastuti, 2014), Wulandari, 2014), dan saham syariah lebih unggul dibandingkan dengan saham nonsyariah (Sapari \& Arifin, 2016; Ruhadi \& Mai, 2017).

Untuk memberi kontribusi terhadap literatur penelitian akuntansi keuangan khususnya dalam kaitannya dengan saham syariah, studi yang sekarang ini menguji dampak saham syariah pada relevansi nilai informasi akuntansi. Penelitian dilakukan dengan membandingkan pengaruh nilai buku ekuitas per saham (book value per share, BVPS) dan laba per saham (earnings per share, EPS) terhadap harga pasar saham. Hasil pengujian ini diharapkan dapat memberi penjelasan apakah informasi tentang saham yang termasuk dalam daftar efek syariah mempunyai dampak terhadap kemanfaatan informasi akuntansi.

\section{KAJIAN TEORI DAN PENGEMBANGAN HIPOTESIS \\ Studi tentang Saham Syariah}

Beberapa studi sebelumnya tentang saham syariah telah dilakukan dengan menggunakan fokus dan hasil yang berbeda-beda. Buchdadi et al. (2010) melakukan perbandingan nilai risiko pada saham berbasis syariah dan saham berbasis non syariah di pasar modal Indonesia selama tahun 2005 - 2008. Perbandingan dilakukan antara saham yang termasuk dalam Jakarta Islamic Index (JII) dan saham yang termasuk dalam indeks LQ 45 dan tidak termasuk dalam saham syariah. Mereka menemukan bahwa saham berbasis syariah lebih berisiko dalam bulan Februari sampai dengan Maret serta dalam bulan Mei sampai dengan Juli.

Berbeda dengan temuan Buchdadi et al. (2010), terdapat studi-studi sebelumnya yang tidak menemukan perbedaan antara saham syariah dan non-syariah. Sebagai contoh, Rosyida \& Mawardi (2015) meneliti perbedaan tingkat pengembalian, risiko dan koefisien variasi saham syariah dan saham non-syariah di Bursa Efek Indonesia (BEI) 2011-2013. Dengan menggunakan Mann-Whitney U, hasil penelitian mereka menunjukkan bahwa tidak ada perbedaan tingkat pengembalian, risiko dan koefisien variasi yang signifikan. Saputra \& Indriani (2016) meneliti perbedaan pengaruh rasio fundamental terhadap return saham syariah dan pengaruh rasio fundamental terhadap return saham non-syariah. Rasio-rasio yang diuji meliputi dividend per share (DPS), dividend payout ratio (DPR), earning per share (EPS), price earning ratio (PER), dan price-to-book value 
(PBV). Mereka menggunakan sampel 10 saham syariah yang terdaftar di Jakarta Islamic Index (JII) dan 10 saham nonsyariah selama periode pengamatan dari tahun 2005 sampai dengan tahun 2009. Hasil studi mereka menunjukkan bahwa hanya price-to-book value (PBV) yang berpengaruh terhadap return saham baik untuk saham syariah maupun untuk saham non-syariah.

Studi-studi sebelumnya yang lain menemukan karakteristik yang berbeda antara saham syariah dan non-syariah dalam beberapa hal. Misalnya, Hamzah (2011) meneliti pengaruh karakteristik perusahaan dan ekonomi makro pada return saham syariah dan non syariah. Dengan menggunakan sampel 300 saham yang terdiri dari 150 saham syariah dan 150 saham non-syariah, Hamzah menemukan perbedaan faktor-faktor yang mempengaruhi return saham syariah dan saham non-syariah. Untuk saham syariah, faktor-faktor yang mempengaruhi return saham meliputi nilai buku, rasio pendapatan barang, dan nilai tukar rupiah terhadap dolar. Untuk saham non-syariah, hanya nilai tukar yang berpengaruh terhadap return saham.

Suhendi \& Indriastuti (2014) membandingkan corporate social responsibility disclosure (CSRD) bank syariah (Bank Mandiri Sharia, BNI Syariah, and BRI Syariah) dan CSRD bank non-syariah (Bank Mandiri, BNI, BRI). Dengan menggunakan Mann-Whitney test, hasil penelitian mereka menunjukkan bahwa bank syariah mengungkap lebih banyak infomasi yang berkaitan dengan aktivitas-aktivitas non-riba, gharar, zakat, saddaqa, waqf, and qard Hasan, sedangkan bank konvensional lebih banyak mengungkap informasi tentang enviromental, energy, dan general information.

Wulandari (2014) membandingkan antara faktor-faktor yang mempengaruhi initial returns setelah initial public offerings (IPO) untuk saham syariah dan faktor-faktor yang mempengaruhi initial returns setelah initial public offerings (IPO) untuk saham non-syariah. Faktorfaktor yang diteliti meliputi stock offering percentage, offer size, profitability, firm size, IPO risk, financial leverage dan liquidity. Dengan menggunakan analisis regresi dan Chow test serta menggunakan sampel sebanyak 72 perusahaan dari 104 perusahaan yang melakukan IPO tahun 2008-2012, hasil penelitian Wulandari menunjukkan bahwa faktor-faktor yang mempengaruhi initial returns untuk perusahaan-perusahaan dengan saham syariah adalah IPO risk, sedangkan faktorfaktor yang mempengaruhi initial returns untuk perusahaan-perusahaan dengan saham non-syariah adalah financial leverage and current ratio.

Temuan studi-studi yang lain menunjukkan bahwa saham syariah lebih unggul dibandingkan dengan saham nonsyariah. Sebagai contoh, Sapari \& Arifin (2016) membandingkan antara nilai value at risk saham syariah dan nilai value at risk saham non-syariah. Studi mereka menggunakan sampel saham syariah yang terdaftar di Jakarta Islamic Index (JII) sebanyak 15 saham dan 25 saham yang terdaftar di Indeks LQ45 sebanyak 25 saham. Dengan menggunakan model GARCH untuk memperkirakan risiko setiap saham, hasil penelitian mereka menunjukkan bahwa saham non-syaria lebih berisiko daripada saham syariah. Ruhadi \& Mai (2017) meneliti apakah perusahaan dengan saham syariah memiliki potensi kebangkrutan yang lebih kecil dari perusahaan non-syariah. Berdasarkan model Altman Z_score, mereka menemukan bahwa kelompok syariah memiliki potensi kebangkrutan yang lebih kecil dari pada non-syariah.

\section{Studi tentang Relevasi Nilai Informasi Akuntansi}

Studi sebelumnya tentang relevansi nilai informasi akuntansi pada umumnya dilakukan dengan berbagai pendekatan. Masruki et al. (2012) meneliti determinan corporate social responsibility (CSR) 
disclosures dari bank-bank di Malaysia. Determinan yang diuji meliputi bank leverage, size, dan profitability. Dengan menggunakan sampel sebanyak 18 bank yang terdiri dari 11 bank lokal dan 7 bank asing serta menggunakan analisis regresi logistik, mereka menemukan bahwa hanya size saya yang merupakan determinan pengungkapan CSR.

\section{Hipotesis Relevasi Nilai Informasi Akuntansi - Saham Syariah dan Non- Syariah}

Informasi akuntansi yang diuji relevansinya adalah nilai buku ekuitas per saham (BVPS) dan laba per saham (EPS). Oleh sebab itu, hipotesis perbandingan antara relevasi nilai informasi akuntansi untuk saham syariah dan relevasi nilai informasi akuntansi untuk saham nonsyariah meliputi dua hipotesis sebagai berikut.

H1. Relevansi nilai BVPS untuk saham syariah lebih tinggi dibandingkan dengan relevansi nilai BVPS untuk saham non-syariah.

H2. Relevansi nilai EPS untuk saham syariah lebih tinggi dibandingkan dengan relevansi nilai EPS untuk saham non-syariah.

\section{METODOLOGI PENELITIAN Variabel}

Variabel-variabel penelitian ini meliputi variabel dependen, variabel independen, variabel pemoderasi (moderating variable), dan variabel interaksi. Variabel dependen adalah harga saham (stock price) yang diberi notasi Price yang merupakan harga saham penutupan perusahaan i pada tahun $\mathrm{j}$. Penelitian ini menggunakan dua variabel independen yaitu (1) nilai buku ekuitas per saham (book value per share) yang diberi notasi BVPS dan (2) laba per saham (earnings per share) yang disingkat EPS. Baik BVPS maupun EPS merupakan nilai pada akhir tahun untuk masing-masing perusahaan dan masing-masing tahun. Variabel pemoderasi dalam penelitian ini adalah SYARIAH merupakan variabel dummy, yang diberi nilai 1 jika saham merupakan saham syariah dan diberi nilai 0 jika saham bukan merupakan saham syariah. Variabel interaksi merupakan hasil perkalian variabel independen dengan variabel pemoderasi yang meliputi BVPSXSYARIAH dan EPSXSYARIAH. Variabel ini digunakan untuk menguji apakah relevansi nilai informasi akuntansi untuk saham syariah lebih tinggi dibandingkan dengan relevansi nilai informasi akuntansi untuk saham nonsyariah.

\section{Metode Analisis}

Metode analisis untuk membandingkan antara relevansi nilai informasi akuntansi untuk saham syariah dan relevansi nilai informasi akuntansi untuk saham non-syariah digunakan model regresi sebagai berikut.

$$
\begin{aligned}
\text { Price }= & \alpha 0+\alpha 1 \text { BVPS }+\alpha 2 \text { EPS }+\varepsilon \\
\text { Price }= & \beta 0+\beta 1 \text { BVPS }+\beta 2 \text { EPS }+ \\
& \beta 3 \text { SYARIAH }+ \\
& \beta \text { B VPSXSYARIAH }+ \\
& \beta 5 \text { EPSXSYARIAH }+v
\end{aligned}
$$

Definisi dan pengukuran variabel dalam dua model regresi disajikan pada subbagian Variabel. Hipotesis 1 didukung jika koefisien $\beta 3$ dalam Model (2) adalah positif dan signifikan, sedangkan hipotesis 2 didukung jika koefisien $\beta 4$ dalam Model (2) adalah positif dan signifikan. Model (1) juga diterapkan untuk kelompok sampel saham syariah dan kelompok sampel saham non-syariah untuk mengetahui relevansi nilai BVPS dan EPS untuk masing-masing kelompok sampel tersebut. Penelitian ini menggunakan effects specification: cross-section fixed (dummy variables) karena data yang digunakan cenderung mempunyai karakteristik data panel. Dengan effects specification tersebut, ditambahkan variabel dummy untuk setiap observasi, meskipun dalam model regresi maupun dalam tabel hasil regresi, variabel dummy tersebut tidak tampak. 


\section{Data dan Sampel}

Data yang digunakan dalam penelitian ini adalah data sekunder yang diambil dari Fact Book dari tahun 2014 sampai dengan tahun 2017 yang memuat data laporan keuangan dan data harga saham tahun 2013-2016. Fact Books tersebut juga digunakan sebagai sample frame. Data harga (Price) saham diambil dari tabel "Number of Listed Shares, Market Capitalization, and Trading", sedangkan data nilai buku per saham (BVPS) dan laba per saham (EPS) diambil dan/atau dihitung dari tabel "Financial Data and Ratios". Pemilihan saham sebagai sampel menggunakan kriteria sebagai berikut: (1) nilai ekuitas dan EPS adalah positif, (2) tanggal pelaporan keuangan adalah 31 Desember, (3) saham terdaftar di Bursa Efek Indonesia selama setahun penuh (saham bukan merupakan saham yang baru saja terdaftar dalam tahun yang bersangkutan dan bukan pula saham yang sudah keluar dari bursa sebelum akhir tahun, (4) perusahaan berada dalam sektor industri selain sektor keuangan (semua sektor kecuali sektor 8), (5) saham aktif diperdagangkan yaitu jumlah transaksi di atas 75 kali selama tiga bulan atau 300 kali dalam satu tahun (Surat Edaran PT Bursa Efek Jakarta Nomor: SE-03/BEJ.ii.1/I/1994). Dengan menggunakan kriteria tersebut di atas, sampel awal yang meliputi 1930 observasi (firm-years) berkurang sebanyak 860 menjadi 1070 observasi.

\section{HASIL DAN PEMBAHASAN Statistik Deskriptif}

Statistik deskriptif untuk sampel secara keseluruhan $(\mathrm{N}=1070)$, untuk kelompok sampel saham syariah $(\mathrm{N}=$ 852), dan untuk kelompok sampel saham non-syariah $(\mathrm{N}=218)$ disajikan pada Tabel 1. Nilai mean harga saham dan EPS non-syariah relatif lebih tinggi dibandingkan dengan nilai mean harga saham syariah. Demikian juga nilai standard deviations harga saham dan EPS non-syariah relatif lebih tinggi lagi dibandingkan dengan nilai mean harga saham syariah dan mengakibatkan koefisien variasi (yaitu deviasi standar dibagi dengan mean) harga saham dan EPS saham non-syariah adalah lebih tinggi dibandingkan koefisien variasi harga saham dan EPS saham non-syariah. Sebaliknya, koefisien variasi BVPS saham syariah adalah lebih tinggi dibandingkan koefisien variasi BVPS saham nonsyariah. Hasil analisis statistik deskriptif tersebut dapat menjadi temuan awal tentang perbandingan antara relevansi nilai BVPS dan EPS saham syariah dan relevansi nilai BVPS dan EPS saham nonsyariah.

Tabel 1. Statistik Deskriptif

\begin{tabular}{lcrrrr}
\hline Variable & Mean & Median & Maximum & Minimum & Std. Dev. \\
\hline \multicolumn{2}{l}{ Panel A: Saham } & Syariah dan & Saham Non-Syariah $(\mathrm{N}=1070)$ & & \\
PRICE & 2456.478 & 615 & 94000 & 50 & 6614.18 \\
BVPS & 2797.082 & 179.1745 & 572705.9 & -517.6471 & 22773.5 \\
EPS & 146.5453 & 39 & 4438 & -550 & 387.401 \\
SYARIAH & 0.796262 & 1 & 1 & 0 & 0.40297 \\
Panel B: Saham Syariah $(\mathrm{N}=852)$ & & & & \\
PRICE & 2201.315 & 650 & 38800 & 50 & 4519.4 \\
BVPS & 3234.916 & 190.7842 & 572705.9 & -517.6471 & 25396.8 \\
EPS & 140.2293 & 42 & 4438 & -456 & 329.565 \\
SYARIAH & 1 & 1 & 1 & 1 & 0 \\
Panel C: Saham Non-Syariah $(\mathrm{N}=218)$ & & & \\
\hline
\end{tabular}




\begin{tabular}{lrrrrr}
\hline PRICE & 3453.72 & 515 & 94000 & 50 & 11582.6 \\
BVPS & 1085.917 & 161.8554 & 64343.14 & -91.84373 & 4665.3 \\
EPS & 171.2297 & 32 & 3797 & -550 & 559.123 \\
SYARIAH & 0 & 0 & 0 & 0 & 0 \\
\hline
\end{tabular}

\section{Korelasi}

Tabel 2 menjajikan korelasi antar variabel-variabel yang diuji yaitu harga saham (Price), nilai buku per saham (BVPS), dan laba per saham (EPS). Korelasi Price dengan EPS relatif lebih tinggi dibandingkan dengan korelasi Price dengan BVPS. Korelasi Price dengan EPS dan BVPS relatif lebih tinggi untuk saham non-syariah dibandingkan untuk saham syariah, tetapi analisis deskriptif menunjukkan bahwa koefisien variasi kedua variabel tersebut juga lebih tinggi untuk saham non-syariah.

Tabel 1. Correlations

\begin{tabular}{|c|c|c|c|}
\hline Variable & PRICE & BVPS & EPS \\
\hline \multicolumn{4}{|c|}{ Panel A: Saham Syariah dan Saham Non-Syariah $(\mathrm{N}=1070$} \\
\hline PRICE & 1 & & \\
\hline BVPS & 0.182551 & 1 & \\
\hline EPS & 0.812421 & 0.335704 & 1 \\
\hline \multicolumn{4}{|c|}{ Panel B: Saham Syariah $(\mathrm{N}=852)$} \\
\hline PRICE & 1 & & \\
\hline BVPS & 0.164867 & 1 & \\
\hline EPS & 0.698112 & 0.235837 & 1 \\
\hline \multicolumn{4}{|c|}{ Panel C: Saham Non-Syariah $(\mathrm{N}=218)$} \\
\hline PRICE & 1 & & \\
\hline BVPS & 0.182551 & 1 & \\
\hline EPS & 0.812421 & 0.335704 & 1 \\
\hline
\end{tabular}

\section{Hasil Regresi}

Hasil regresi untuk menguji relevansi nilai buku per saham (BVPS) dan laba per saham (EPS) disajikan pada Tabel 3. Hasil regresi model (1) menunjukkan bahwa koefisien BVPS dan koefisien EPS adalah positif dan signifikan pada level 1\%. Hasil ini mengindikasi bahwa baik BVPS maupun EPS mempunyai relevansi nilai, yaitu bahwa baik BVPS maupun EPS berhubungan positif dengan harga saham (Price). Selanjutnya, hasil regresi pada model (2) menunjukkan bahwa koefisien variabel interaksi BVPSXSYARIAH adalah positif dan signifikan pada level $1 \%$, sedangkan koefisien variabel interaksi BVPSXSYARIAH adalah negatif dan signifikan pada level 1\%. Hasil ini bermakna bahwa relevansi nilai BVPS untuk saham syariah lebih tinggi dibandingkan dengan relevansi nilai BVPS untuk saham non-syariah, tetapi relevansi nilai EPS untuk saham syariah lebih rendah dibandingkan dengan relevansi nilai EPS untuk saham non-syariah. 


\begin{tabular}{lll} 
F-statistic & 21.16379 & 7.978657 \\
Prob(F-statistic) & 0.000000 & 0.000000 \\
\hline \hline - & Variabel Dependen: Price (Harga Saham) \\
- & BVPS = Book Value per Share (Nilai Buku per Saham) \\
- & EPS = Earnigs per Share (Laba per Saham) \\
- & BVPSxSYARIAH = Perbandingan pengaruh BVPS terhadap harga \\
& saham (saham syariah dan non-syariah) \\
- & EPSxSYARIAH = Perbandingan pengaruh EPS terhadap harga \\
& saham (saham syariah dan non-syariah) \\
- & Effects Specification: Cross-section fixed (dummy variables) \\
\hline \hline
\end{tabular}

\section{Pembahasan}

Penelitian ini mendapatkan bukti empiris bawa baik BVPS dan EPS mempunyai relevansi nilai, yaitu bahwa kedua variabel tersebut berhubungan positif dengan harga saham, atau semakin tinggi BVPS dan EPS semakin tinggi pula harga saham. Hasil mengkonfirmasi manfaat informasi akunansi dalam pengambilan keputusan investasi saham yang sudah diuji dalam studi-studi sebelumya tentang relevansi nilai informasi akuntansi yang dalam hal ini adalah BVPS dan EPS. Selanjutnya, temuan penelitian ini menunjukkan bahwa informasi BVPS untuk saham syariah mempunyai relevansi nilai yang tinggi dibandingkan dengan informasi BVPS untuk saham non-syariah. Hal ini mengindikasi bahwa informasi tentang saham yang termasuk dalam daftar efek syariah (DES) dapat meningkatkan relevansi nilai informasi BVPS. Sebagaimana ditetapkan dalam Keputusan Ketua Badan Pengawas Pasar Modal Dan Lembaga Keuangan Nomor: Kep208/B1/2012 Tentang Kriteria Dan Penerbitan Daftar Efek Syariah, saham yang dimasukkan dalam DES adalah saham yang memiliki karakteristik yang secara umum adalah tidak bertentangan dengan prinsip-prinsip syariah di pasar modal. Secara lebih khusus, kegiatan usaha beserta cara pengelolaan usaha dari perusahaan dengan saham yang termasuk dalam DES dilakukan berdasarkan prinsip syariah dan tertuang dalam anggaran dasar perusahaan tersebut serta memenuhi rasiorasio keuangan sebagai berikut: (1) total utang yang berbasis bunga dibandingkan dengan total aset tidak lebih dari $45 \%$ (empat puluh lima per seratus); atau (2) total pendapatan bunga dan pendapatan tidak halal lainnya dibandingkan dengan total pendapatan usaha (revenue) dan pendapatan lain-lain tidak lebih dari $10 \%$ (sepuluh per seratus).

\section{KESIMPULAN DAN SARAN Simpulan}

Temuan penelitian ini menunjukkan bahwa untuk saham syariah dan saham non-syariah, nilai buku per saham (BVPS) dan laba per saham (EPS) mempunyai relevansi nilai yaitu bahwa variabelvariabel mempunyai hubungan positif dengan harga saham. Selanjutnya, temuan berikutnya menunjukkan bahwa relevansi nilai BVPS untuk saham syariah lebih tinggi dibandingkan dengan relevansi nilai BVPS untuk saham non-syariah. Namun, temuan penelitian ini juga menunjukkan bahwa relevansi nilai relevansi nilai EPS untuk saham syariah tidak berbeda dibandingkan dengan relevansi nilai EPS untuk saham non-syariah. Dengan demikian, saham yang termasuk dalam daftar efek syariah (DES) mempunyai keunggulan dibandingkan dengan saham yang tidak termasuk dalam DES, yaitu mempunyai informasi akuntansi, yang dalam hal ini BVPS, yang direspon lebih tinggi oleh investor. Hasil ini bisa disebabkan oleh kriteria yang dipenuhi 
oleh perusahaan yang mempunyai saham yang termasuk dalam DES merupakan signal positif bagi investor dalam memaknai informasi akuntansi yang terkandung dalam laporan keuangan khususnya informasi BVPS.

\section{Implikasi}

Hasil penelitian ini dapat digunakan sebagai bahan pertimbangan bagi perusahaan yang menawarkan sahamnya di Bursa Efek Indonesia (BEI) untuk menggunakan kriteria DES dalam mengelola perusahaannya. Temuan ini juga dapat menjadi bahan pertimbangan bagi investor dan/atau calon investor yang ingin melakukan analisis laporan keuangan dalam rangka pengambilan keputusan investasi saham dan belum mempertimbangkan informasi tentang DES. Hasil studi ini juga dapat digunakan oleh regulator pasar modal yaitu sebagai salah satu referensi dalam menjelaskan manfaat DES.

\section{Keterbatasan}

Keterbatasan penelitian ini antara lain bahwa pemilihan saham sebagai sampel tidak dilakukan secara random sehingga hasil penelitian ini tidak dapat digeneralisasi untuk saham-saham di luar sampel. Pengambilan sampel dengan kriteria tertentu ini diperlukan dengan pertimbangan-pertimbangan tertentu. Sebagai contoh, saham-saham di sektor keuangan yang tidak dimasukkan ke dalam sampel mengakibatkan bahwa sampel jumlah saham non-syariah menjadi relatif sedikit. Meskipun demikian, pengeluaran saham di sektor keuangan dari sampel mempunyai tujuan tertentu yaitu untuk menghindari bias hasil penelitian karena hampir semua saham di sektor keuangan merupakan saham non-syariah dan hasil perbandingan saham syariah dan nonsyariah bisa dipengaruhi oleh perbedaan sektor industri.

Saran untuk Penelitian Selanjutnya

Penelitian perbandingan relevansi informasi akuntansi secara umum dan informasi BVPS dan EPS secara khusus untuk saham-saham yang tidak termasuk ke dalam sampel dapat dilakukan secara khusus dengan metode yang berbeda misalnya dengan menggunakan studi kasus. Penelitian ini dapat juga diuji ulang dengan menggunakan periode pengamatan yang berbeda untuk menguji validitas hasil penelitian ini.

\section{REFERENSI}

Albaity, Mohamed, and Rubi Ahmad. "A Comparative Analysis of the Firm Specific Determinants of Syariah Compliant Versus Non-Syariah Compliant Firms in Bursa Malaysia." Asian Journal of Business and Accounting 4.1 (2011).

Ashraf, D. (2016). Does shari'ah screening cause abnormal returns? empirical evidence from islamic equity indices. Journal of Business Ethics, 134(2), 209-228.

http://dx.doi.org/10.1007/s10551-0142422-2

Buchdadi, Agung D., M. Yasser Arafat, and Tri Hesti Utaminingtyas. "The Comparison of Value at Risk on Sharia Based Stock and Non-Sharia Based Stock (Case study on Indonesia Capital Market during." Rapid City, South Dakota September 30-October 3, 2010 (2010).

Bukhari, Syed Kalim Hyder and Mohammed Azam. 2015. "A Comparative Returns Performance Review of Islamic Equity Funds with Socially Responsible Equity Funds and the Broader Market Indices." The Lahore Journal of Economics 20 (2): 53-75.

https://search.proquest.com/docview/ 1762710344 ? accountid=25704.

Hamzah, Ardi. "Analisis Karakteristik Perusahaan Dan Ekonomi Makro Pada Return Saham Syariah Dan Non Syariah." AKRUAL: Jurnal Akuntansi 3.1 (2011): 70-86.

Mohammed, Mustafa Omar, Kazi Md Tarique, and Rafikul Islam. 2015. 
"Measuring the Performance of Islamic Banks using Maqasid-Based Model." Intellectual Discourse 23: 401-424.

https://search.proquest.com/docview/ 1760941233 ? accountid=25704.

Nainggolan, Yunieta, Janice How, and Peter Verhoeven. 2016. "Ethical Screening and Financial Performance: The Case of Islamic Equity Funds." Journal of Business Ethics 137 (1): 83-99.

doi:http://dx.doi.org/10.1007/s10551014-2529-5. $\quad$ https://search. proquest.com/docview/1811104700?a ccountid=25704.

Ratnaningrum, Ratnaningrum, and Heni Susilowati. "Analisis Faktor-Faktor Yang Mempengaruhi PER Antara Saham Yang Tercatat Dalam Index Syariah Dan Saham Biasa (Studi pada Perusahaan Non Keuangan di Bursa Efek Indonesia 2006-2008)." Benefit: Jurnal Manajemen dan Bisnis 14.1 (2011): 17-30.

Rosyida, Ajeng Gama, and Imron Mawardi. "Perbandingan Tingkat Pengembalian (Return), Risiko dan Koefisien Variasi Pada Saham Syariah dan Saham Non Syariah di Bursa Efek Indonesia (BEI) Periode 2011-2013." Jurnal Ekonomi Syariah Teori dan Terapan 2.4 (2015).

Ruhadi, Ruhadi, and Muhammad Umar Mai. "Bankruptcy Model Analysis: Comparative Studies Between Sharia and Non Sharia Manufacturing Companies." Al-Iqtishad: Jurnal Ilmu Ekonomi Syariah 9.2 (2017): 311330.

Sapari, Fransissco Nicolas, and Agus Zainul Arifin. "Studi Perbandingan Nilai Value at Risk Antara Saham Berbasis Syariah Dengan Saham Non Syariah Periode 2010-2012." Jurnal Dinamika Akuntansi dan Bisnis 3.1 (2016): 26-36.

Saputra, Dedi Oktrihadi, and Rini Indriani. "Pengaruh Rasio Analisis Fundamental Terhadap Return
Saham: Perbedaan Pengaruh Antara Saham Syariah dan Non Syariah." Jurnal Akuntansi dan Keuangan 2.1 (2016).

Suhendi, Chrisna, and Maya Indriastuti. "CSR Disclosure Evidence In Indonesia: Sharia And Non Sharia Bank." South East Asia Journal of Contentporary Business, Economic and Law 4 (2014): 30-34.

Wulandari, Renny. "Initial Return: Perbedaan Saham Syariah Dan Non Syariah Di Pasar Modal Indonesia." Akuntabilitas 7.1 (2014): 26-41. 